\title{
1 Soil Aggregate Stability of Forest Islands and Adjacent Ecosystems in 2 West Africa
}

Amelie Baomalgré Bougma ${ }^{1}$, Korodjouma Ouattara $^{1}$, Halidou Compaore ${ }^{1}$, Hassan Bismarck. Nacro ${ }^{2}$, Caleb Melenya ${ }^{3}$, Samuel Ayodele Mesele ${ }^{4}$, Vincent Logah ${ }^{3}$, Azeez Jamiu Oladipupo ${ }^{4}$, Elmar

Veenendaal $^{5}$, Jonathan Lloyd $d^{6,7,8}$

$7{ }^{1}$ Institut de l'Environnement et de Recherches Agricoles (INERA), Burkina Faso, 04 BP 8645 Ouagadougou 04, Burkina Faso

$8{ }^{2}$ Université Nazi BONI (UBN), 01 BP 910, Bobo, 01 Burkina Faso.

$9{ }^{3}$ Kwame Nkrumah University of Science and Technology, Kumasi, Ghana

$10 \quad{ }^{4}$ Federal University of Agriculture, Abeokuta (FUNAAB), PMB 2240 Abeokuta, Nigeria.

11 5ature Conservation and Plant Ecology Group, Wageningen University and Research, Droevendaalsesteeg 3a, 6700 AA,

12 Wageningen, Netherlands

$13{ }^{6}$ Department of Life Science, Imperial College London, Silwood Park Campus, Buckhurst Road, Ascot, SL5 7PY, UK.

$14{ }^{7}$ School of Tropical and Marine Sciences and Centre for Terrestrial Environmental and Sustainability Sciences, James Cook

15 University, Cairns, 4870, Queensland, Australia

$16{ }^{8}$ Universidade de São Paulo, Faculdade de Filosofia Ciências e Letras de Ribeirão Preto, Av Bandeirantes, 3900, CEP 14040-

17 901, Bairro Monte Alegre, Ribeirão Preto, SP, Brazil

*Correspondence to: Amelie B. Bougma (ameliebougma@yahoo.fr)

Abstract. In the more mesic savanna areas of West Africa, significant areas of relatively tall and dense vegetation with a species composition more characteristic of forest than savanna are often found around villages areas. These 'forest islands' may be the direct action of human activity. To better understand the processes leading to the development of these patches with relatively luxuriant vegetation, our study focused on the stability of the soil aggregates of forest islands, nearby areas of natural savanna vegetation across a precipitation transect in West Africa for which mean annual precipitation at the study sites ranges from 0.80 to $1.27 \mathrm{~m} \mathrm{a}^{-1}$. Soil samples were taken from 0 to $5 \mathrm{~cm}$ and 5 to $10 \mathrm{~cm}$ depths and aggregate fractions with diameters: $>500 \mu \mathrm{m}, 500-250 \mu \mathrm{m}$ and 250-53 $\mu \mathrm{m}$ (viz. "macro aggregates", "mesoaggregates" and "microaggregates") determined using the water sieving method. The results showed significant higher proportion of stable meso and macroaggregates in forest islands and natural savanna compared to agricultural soils $(\mathrm{p}<0.05)$. On the other hand, although there was no effect of land-use type on microaggregates stabilities, there was a strong tendency for the micro-aggregate fraction across all land use types to increase with increasing precipitation. Simple regression analyses showed soil organic carbon and iron oxides contents as the most important factors influencing aggregate stability in West African ecosystems.

Keywords: Sites, land use, macro-aggregates, micro-aggregates, West Africa

\section{Introduction}

In West Africa, both natural and human dominated ecosystems are often affected by land degradation processes, with soil erosion usually considered the most severe threat to long term sustainability. The erosion process itself results from a complex combination of climatic and anthropogenic factors (Zombre, 2003). In general, aggregate stability is a key metric used for 
https://doi.org/10.5194/soil-2019-87

Preprint. Discussion started: 8 January 2020

(c) Author(s) 2020. CC BY 4.0 License.

assessing soil susceptibility to erosion (Barthès and Roose, 2002) as it strongly influences the rates of water infiltration and runoff, and plays a key role in the dynamics and stabilization of soil organic matter (Six et al., 2000). The aggregate formation process itself is a complex process influenced by soil organic matter content, climate conditions, soil type, soil mineralogy and land use patterns (Ezebilo, 2004; Six et al., 2004; Ouattara et al., 2008; Mataix-Solera et al., 2011). Most recently, several studies showed the role of soil organisms and vegetation structure and/or species composition as additional factors influencing the stability of soil aggregates (Six et al., 2000; Chartier et al., 2011; Berendse et al., 2015; Gould, 2016). With a species and structural composition more typical of forest stands found in humid regions, "islands" of dense vegetation typically of 0.1 to 10 ha area are often found surrounding many village areas in the West African mesic savanna zones where they are thought to have resulted from, at least in part, from the conscious actions of the nearby village occupants (Leach and Fairhead, 1995; Jones, 1963). There have, however, been few studies on the role of such "Forest Islands" (FI) and their unique ecological characteristics (Kokou and Sokpon, 2006), apart from the descriptive analyses of few soil profiles ( Sobey, 1978; Fairhead and Leach, 1998).

This study aims to contribute to the knowledge of the edaphic properties of FI (Forest island) through by assessing soil aggregate size distributions in adjacent savannas (considered to be the typical 'natural' vegetation of the region) and cultivated fields. Considering some recent studies on the importance of biodiversity and vegetation cover on soil quality (Chartier et al., 2011; Berendse et al., 2015; Gould, 2016), we hypothesized that soil aggregate stability is higher under forest islands than in adjacent savanna or agricultural field.

\section{Material and methods}

\subsection{Sampling locations and site descriptions}

The study was carried out in 2016 in 11 locations across Burkina Faso, Ghana and Nigeria. The study sites were distributed across three agro-ecological zones (AEZ) (Figure 1) as defined by Ker (1995). At each of the eleven location, three land use types were selected for sampling as follows:

2.1.1 Forest island (FI) plots consisted of patches of forests around villages with open landscape mosaic of relatively open savanna vegetation and agricultural fields. The trees are tall, being 15 to $20 \mathrm{~m}$ high with typically more than 400 individuals per hectare with diameter at breast height $(D)$ greater than $10 \mathrm{~cm}$,

2.1.2 Savanna (SA) plots may be considered as natural vegetation type from all three agro ecological zones (AEZ). Trees were typically between 5 to $10 \mathrm{~m}$ high and with a density of 50 to 100 trees $(D>10 \mathrm{~cm})$ per hectare. Due to their open nature, these savanna formations were typically with an abundant ground layer of grasses and herbs.

2.1.3 Agricultural field plots (AF) were selected are close as possible to the FI and SA plots and, from discussions with local village inhabitants, had been exposed to at least 10 years of cultivation. In Burkina Faso, the cropland study sites were cotton based or cereals based fields. In Ghana, the cropping areas were monocultures of maize. In Nigeria, they were maize or mixture of maize/cassava or legumes.

\subsection{Soil sampling}

At each of the 11 locations, soil samples were collected from FI, SA and AF. The size of the sampling area was 0.16 ha which was divided into four $20 \times 20 \mathrm{~m}$ subplots for soil sampling. Within each subplot at least five samples were taken from 0-5 and 5-10 cm depth using undisturbed soil sampling auger (Eijkelkamp Agrisearch Equipment BV, Giesbeek, The Netherlands). Samples were subsequently air-dried and stored for laboratory analysis. 
https://doi.org/10.5194/soil-2019-87

Preprint. Discussion started: 8 January 2020

(c) Author(s) 2020. CC BY 4.0 License.

\subsubsection{Soil aggregate stability}

The wet seiveing method (Mathieu and Pieltain, 1998) was used to determine soil aggregate stability. This method consists of passing air-dried soil samples through $4000 \mu \mathrm{m}, 500 \mu \mathrm{m}, 250 \mu \mathrm{m}$ and $53 \mu \mathrm{m}$ sizes sieves (not sequentially) to obtain three aggregate fractions defined as "macroaggregates" (4 mm-500 $\mu \mathrm{m})$, "mesoaggregates" (500-250 $\mu \mathrm{m})$ and "microaggregates" $(250-53 \mu \mathrm{m})$. To obtain each aggregate class, $3 \mathrm{~g}$ of soil sample previously moistened by spraying with distilled water was placed on sieves of either $500 \mu \mathrm{m}$ (macroaggregates), $250 \mu \mathrm{m}$ (mesoaggregates) or $53 \mu \mathrm{m}$ (microaggregates). The sieves were then placed on the wet sieving equipment, and shaken slowly backwards and forward for one hour until all the unstable aggregates passed through the sieve mesh.

At the end of the sieving procedure, aggregate fractions were collected in a cup, oven dried at $105^{\circ} \mathrm{C}$ for 24 hours and then weighed. The sand fraction of each aggregate fraction was then determined after destruction of organic matter by adding $3 \mathrm{ml}$ of hydrogen peroxide by heating till all bubbles disappeared from the soil-water mixture, after which the solution was made up to $75 \mathrm{ml}$ with distilled water and the soil particles dispersed using sodium hexametaphosphate. Afterwards, samples were washed on a $0.5 \mathrm{~mm}$ sieve and then dried and weighed. The fraction of soil stable aggregates $\left(\Phi_{\mathrm{A}}\right)$ was then calculated using the following formula (Bloin et al., 1990)

$$
\Phi_{\mathrm{A}}=\left(P_{\mathrm{ag}}-P_{\mathrm{s}}\right) /\left(P_{\mathrm{e}}-P_{\mathrm{s}}\right)
$$

where $\mathrm{P}_{\mathrm{ag}}=$ the dried total soil remaining in the sieve, $\mathrm{P}_{\mathrm{e}}=$ the weight of soil sample used and $\mathrm{P}_{\mathrm{s}}=$ weight of the sand in the sample.

2.2.2 Particle size analysis

The separation of the sand, silt and clay fractions were done using Robinson-Köhn method. This method consists of destruction of organic matter by hydrogen peroxide followed by particle dispersion with sodium hexametaphosphate, with subsequent separation of silt and clay particles by sedimentation with sands by sieving (Mathieu and Pieltain, 1998).

\subsubsection{Chemical analysis}

Soil $\mathrm{pH}$ was measured using the electrode method in a ratio of soil / water of 1: 2.5. Total soil carbon content was determined in an automated elemental analyzer (Vario MACRO cube, Elementar Germany). Soil total and available Fe were determined by direct colorimetry after etching with concentrated hydrochloric acid and sodium hydrosulfite (Mehrotra, 1992).

\subsubsection{Statistical analysis}

In order to evaluate the potential joint effects of mean annual precipitation (v), land-use (L) and sampling depth (d) on the three aggregate fractions, we fitted a mixed effect model allowing for stratified nature of the sampling design according to

$$
\log _{10}\left[\arcsin \left(f_{\mathrm{dcp}}\right)\right]=\alpha_{000}+\alpha_{001} P_{\mathrm{A} 00 \mathrm{p}}+\gamma_{\mathrm{i}} L_{00 \mathrm{p}}+\gamma_{\mathrm{j}} d_{0 \mathrm{cp}}+U_{00 \mathrm{p}}+V_{0 \mathrm{cp}}+R_{\mathrm{dcp}} \quad,
$$


https://doi.org/10.5194/soil-2019-87

Preprint. Discussion started: 8 January 2020

(c) Author(s) 2020. CC BY 4.0 License.

where $f_{d c p}$ is the aggregate fraction $f$ as measured at depth $d$ of core $c$ in plot $p ; \alpha_{000}$ is the overall mean value of $\mathrm{f}$ at 0 to $5 \mathrm{~cm}$ depth for agricultural fields (AF) across the dataset (intercept term with all model input centered on the dataset mean annual precipitation $\left(\mathrm{P}_{\mathrm{A}}\right)$ of $\left.1.01 \mathrm{~m} \mathrm{a}^{-1}\right), \alpha_{001}$ is a fitted variable describing the response of $\mathrm{f}$ to $\mathrm{P}_{\mathrm{A}}, \gamma_{\mathrm{i}}$ is the response of $\mathrm{f}$ to the land use indicator variable $\mathrm{L}$ (for which $\mathrm{AF}=0$, forest island $(\mathrm{FI})=1$ and savanna $(\mathrm{SA})=2$ ); $\gamma_{\mathrm{j}}$ is the difference in $\mathrm{f}$ between the upper and lower sampling depths for core $\mathrm{c}$ within plot $\mathrm{p}$; $\mathrm{U}_{00 \mathrm{p}}$ represents the variance associated with plot location (i.e. the systematic component of the plot variation that is not accounted for by the precipitation and land use terms); $\mathrm{V}_{0 \mathrm{cp}}$ is the withinplot variation (i.e. the variance associated with the sampling of replicate cores within individual plots) and $R_{\mathrm{dcp}}$ is the residual variance.

In terms of the fixed components, it is worth noting that (2) can also be written as (ignoring subscripts where possible for convenience)

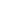

$$
f=\sin \left(10^{\left[\alpha_{0}+\alpha_{1} P_{\mathrm{A}}+\gamma_{\mathrm{i}} L+\gamma_{\mathrm{j}} d\right]}\right)=\sin \left(10^{\left[\alpha_{0}+P_{\mathrm{A}}\right]} 10^{\gamma_{\mathrm{i}} L} 10^{\gamma_{\mathrm{j}} d}\right),
$$

which illustrates the essentially multiplicative nature of the untransformed model. In terms of precipitation sensitivities, Equation 3 may also be differentiated as (taking the indicator variables $\gamma_{0}$ and $\gamma_{\mathrm{i}}$ as zero $(=\mathrm{AF})$ for simplicity)

$$
\frac{d f}{d\left\langle P_{\mathrm{A}}\right\rangle}=\alpha_{1} \cdot \cos \left(10^{\left[\alpha_{0}+\alpha_{1} P_{\mathrm{A}}\right]}\right) \cdot 10^{\left[\alpha_{0}+\alpha_{1} P_{\mathrm{A}}\right]} \cdot \log (10),
$$

Note that for the fitting of the mixed model, the input precipitations were centered on the dataset mean of $1.01 \mathrm{~m} \mathrm{a}^{-1}$. This means that, once appropriately back transformed, the fitted intercept gives an estimate of $\mathrm{f}$ at the dataset mean precipitation rather than the (relatively meaningless) $\mathrm{P}_{\mathrm{A}}=0 \mathrm{~m} \mathrm{a}^{-1}$.

\section{Results}

\subsection{Effects of rainfall pattern and land use on aggregate fractions}

Figure 2 shows the variations in the three aggregate fractions with land use type and precipitation $(0$ to $5 \mathrm{~cm}$ depth only) with the fitted lines coming from the mixed model analysis of Table 2. For the micro aggregates (Fig 2a), there was a strong increase in relative abundance with precipitation $(p<0.001)$ but no effect of land use $(p>0.1)$ with the intercept of -0.030 equating to a predicted $f_{\text {micro }}$ of $\sin \left(10^{-0.03}\right)=0.803$ for agricultural fields $(\mathrm{AF})$ at the dataset mean of $1.01 \mathrm{a}^{-1}$, and with the associated coefficient of $0.976 \pm 0.272 \mathrm{~m}^{-1}$ equating to an increase of $0.975 \times\left[10^{-0.03} \cos \left(10^{-0.03}\right)\right] \times \log (10)=1.24 \mathrm{~m}^{-1}$, viz. with each $10 \mathrm{~mm}$ increase in $P_{\mathrm{A}}$ being associated with a relative increase in $f_{\text {micro }}$ of $1.24 / 0.803=1.6 \%$. Although the fitted equation is linear in form, due to the dual logarithmic and arcsine transformations, $f_{\text {micro }}$ is clearly a saturating function of. For example, at a lower $=0.80 \mathrm{a}^{-1}$ then $f_{\text {micro }}=\sin \left(10^{[-0.03+(0.976 \mathrm{x}-0.201)]}\right)=0.561$ and with the relative increase in $f_{\text {micro }}$ per $10 \mathrm{~mm}$ of $P_{\mathrm{A}}$ equal to $1.9 \%$. Likewise, for the higher $P_{\mathrm{A}}=1.20 \mathrm{a}^{-1}$ we obtain through equivalent calculations a predicted $f_{\text {micro }}$ of 0.994 and with each $10 \mathrm{~mm}$ increase in rainfall being associated with an relative increase in $f_{\text {micro }}$ of just $0.2 \%$. Although for the sake of clarity (not shown in Fig 2a), from Table 2, it is also evident that there is an effect of depth $(p<0.05)$ with the regression coefficient 
https://doi.org/10.5194/soil-2019-87

Preprint. Discussion started: 8 January 2020

(c) Author(s) 2020. CC BY 4.0 License.

of $-0.086 \pm 0.029 \mathrm{~m}^{-1}$ suggesting that $f_{\text {micro }}$ were typically $13.7 \%$ lower at 5 to $10 \mathrm{~cm}$ depth than was the case for the upper 0 to $5 \mathrm{~cm}$ at the data set average of $P_{\mathrm{A}}=1.01 \mathrm{~m} \mathrm{a}^{-1}$. Due to the dual $\log _{10} \times$ arcsine transformation employed as part of Equation 2 , there is a slight dependency of this (relative) depth difference on $P_{\mathrm{A}}$ in the model with the lower layer modelled to be $13.1 \%$ lower at $\left\langle P_{\mathrm{A}}\right\rangle=0.8 \mathrm{~m} \mathrm{a}^{-1}$ and $14.2 \%$ lower at $P_{\mathrm{A}}=1.20 \mathrm{~m} \mathrm{a}^{-1}$.

For both the mesoaggregates (Fig. 2b) and macroaggregates (Fig. 2c), very different patterns of variation were observed with there being no dependence of aggregate fraction on $P_{\mathrm{A}}$ but with effects of land-use being observed in both cases (Table 2). For example, again calculating at the data set average $P_{\mathrm{A}}=1.01 \mathrm{~m} \mathrm{a}^{-1}$ we obtain for estimates for $f_{\text {meso }}=\sin \left(10^{-0.805}\right)=0.15$ for $\mathrm{AF}$ and with forest island (FI) and savanna (SA) modelled to have $f_{\text {meso }}$ that were, on average, $122 \%$ and $67 \%$ higher respectively - but with only the FI-AF difference being significant at $p<0.05$. As for $f_{\text {micro }}$ there was an effect of sampling depth on $f_{\text {meso }}$ with values of the $5-10 \mathrm{~cm}$ depth typically being $10^{-0.141}=26 \%$ lower than is observed at 0 to $10 \mathrm{~cm}$ depth.

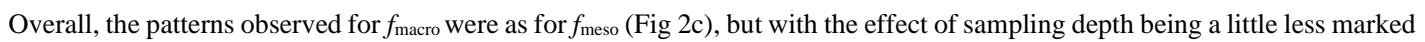
(Table 2).

Also of interest in Table 2 are the variances associated with the random components, for which it can be seen that, although for the microaggregates the between-plot variance $\left(\tau^{2}\right)$ was slightly less than the residual variance $\left(\sigma^{2}\right)$, for both the meso and macroaggregates $\left(\tau^{2} \gg \sigma^{2}\right)$ indicating that there was much more systematic between-plot variation that could not be accounted for by the either precipitation or land-use for the two larger aggregate types. For all three aggregate sizes examined, the within-plot variance was the smallest component: This indicates that, after accounting for systematic land-use and precipitation effects, that the variation within a plot was typically less than was between plots, and with this within-plot variance also being typically less than the variation within individual soil cores after accounting for systematic depth effects. There were higher $(p<0.05)$ proportion of stable meso and macro- aggregates in forest islands and natural savanna compared to agricultural soils (Table 3).

\subsection{Underlying basis of differences in aggregate fractions}

Using Kendall's $\tau$ and taking mean values per plot (upper 0 to $5 \mathrm{~cm}$ depth only), Table 4 details the strength of associations between the three aggregate fractions as well as correlations with and between measures of soil citrate-, dithionate- and pyrophosphate-extractable aluminium and iron, soil carbon and mean annual precipitation. This shows, as might be expected from Fig. 2a, that for $f_{\text {micro }}$ there was a strong positive association with $P_{\mathrm{A}}(\tau=0.50 ; p<0.0001)$, and with a weaker negative association with pyrophosphate-extractable aluminium also of note $(\tau=-0.26 ; p=0.051)$. On the other hand, for $f_{\text {meso }}$ it was the dithionate-extractable aluminium $\left[\mathrm{Al}_{0}\right]$ that showed the strongest (negative) correlation $(\tau=-0.28 ; p=0.032)$, and with both dithionate-extractable iron $\left[\mathrm{Fe}_{\mathrm{d}}\right](\tau=-0.26 ; p=0.068)$ and dithionate-extractable aluminium $\left[\mathrm{Al}_{\mathrm{d}}\right](\tau=-0.26 ; p=0.072)$ as well as soil $[\mathrm{C}]$ also being positively associated $(\tau=0.26 ; p=0.047)$. Overall, across sites, there was a very strong association between $f_{\text {meso }}$ and $f_{\text {macro }}(p<0.0001)$, with soil $[\mathrm{C}]$ appearing to be a much stronger determinant of the latter $(\tau=0.42 ; p=$ $0.0012)$. Also of note, $\left[\mathrm{Fe}_{\mathrm{d}}\right]$ also showed a modestly strong correlation with $f_{\text {macro }}(\tau=-0.25 ; p=0.053)$. 
https://doi.org/10.5194/soil-2019-87

Preprint. Discussion started: 8 January 2020

(c) Author(s) 2020. CC BY 4.0 License.

In order to separate out the potentially causative versus correlative factors, partial Kendall correlation coefficients $\tau_{\mathrm{P}}$ were subsequently employed. For example, for $f_{\text {meso }}-$ testing for $\left[\mathrm{Al}_{\mathrm{o}}\right],\left[\mathrm{Al}_{\mathrm{d}}\right],\left[\mathrm{Fe}_{\mathrm{d}}\right]$ and $[\mathrm{C}]$ separately (whilst in each case controlling for variation in the other three covariates) - all of $\left[\mathrm{Al}_{\mathrm{o}}\right],\left[\mathrm{Al}_{\mathrm{d}}\right]$ and $\left[\mathrm{Fe}_{\mathrm{d}}\right]$ were all found to be with $\left|\tau_{P}\right|<0.22$ and with $p>0.1$; the best of the four tested predictors being [C] for which $\tau_{\mathrm{P}}=0.23$ and $p=0.093$. Although this result for $f_{\text {meso }}$ must be regarded as negative, a similar analysis confirmed a unequivocal strong role for [C] in accounting for site-to-site variations in $f_{\text {macro }}\left(\tau_{\mathrm{P}}=0.39 ; p=0.004\right)$, although with all three other tested variables all having $\left|\tau_{P}\right|<0.2$ and with an associated $p>0.2$. For $f_{\text {micro }}$ the same partial Kendall's analysis suggested nothing other than a strong role for $P_{\mathrm{A}}$ in accounting for the variations observed as already indicated (Tables 2 and 3). With the $f_{\text {micro }} v s . P_{\mathrm{A}}$ association already shown in Fig $2 \mathrm{a}$, Fig. 3 shows the nature of the significant $f_{\text {macro }} v s .[C]$ association across sites.

\section{Discussion}

Our data showed strong influence of precipitation on soil micro-aggregates whereas land use type influenced the larger aggregate groups - meso and macro (Table 2$)$. The gradual increase in stable soil micro aggregates $\left(f_{\text {micro }}\right)$ with precipitation may be a result of seasonal variation in soil moisture and soil drying-wetting cycles which has impact on soil microbial activity often considered a binding agent in soil aggregate formations. Micro-aggregates may initially form by the progressive bonding of primary particles of clay, SOM (soil organic matter) and cations, with fungal and bacterial debris giving rise to extremely stable micro-aggregates (Bongiovanni and Lobartini, 2006; Bouajila and Gallali, 2008).

Macro-aggregates fall apart in response to major rainfall events due to disruptive forces (wetting and drop impact) which contributes to release of more micro-aggregates during rainfall (Bach and Hofmockel (2015). It has, for example, been reported that increasing soil moisture results in a lower shear strength of wet aggregates and consequently a higher vulnerability to raindrop impact. Regardless of the aggregate hierarchy theory, drying/wetting plays a key role on macro turnover releasing micro-aggregates (Tisdall et al., 1982; Six et al., 2004; Bach and Hofmockel, 2015) which may increase the local concentration of enzymes to stimulate microbial activity and increase continual carbon turnover.

The fact that land use influenced meso and macro aggregates across locations is attributable to management benefits arising from differences in soil organic carbon content and vegetation characteristics, explaining to some extent the positive correlations observed between soil organic matter content and aggregate stability (Table $4 \&$ Figure 2). Soil organic carbon is known to improve aggregate stability via different mechanisms and by its different fractions as a result of inner sphere interaction between the carboxyl groups and cations of the mineral structure through ligand exchange mechanism (Mikutta et al., 2011). Although other organo-mineral interactions have also been proposed viz. hydrophobic interactions, cation bridges; cation and anion exchange; and Van der Waals interactions, among others (Hanke et al., 2015, Hanke and Dick, 2017), these have not been well investigated.

The higher proportion of macro-aggregates in forest islands and natural savanna than in the cultivated soils (Table 3) indicated negative effects of cultivation on soil aggregation. In cropland, disaggregation of macro-aggregates due to frequent tillage (Ouattara, 2007; Six et al., 2000) is known to be a key factor leading to less stable aggregates. This is because frequent plowing leads to physical disruption of aggregates which is highly vulnerable to soil stability (Six et al., 2004). Moreover, plowing 
https://doi.org/10.5194/soil-2019-87

Preprint. Discussion started: 8 January 2020

(c) Author(s) 2020. CC BY 4.0 License. 3

causes loss of soil organic matter via increased mineralization with negative implications on aggregate stability. Similar results have also been reported by Cerdà, (2000) who found higher soil aggregate stability in forest than in cropland in southern Bolivia. Likewise Erktan et al. (2015) and Wang et al. (2012) reported decline in soil aggregate stability resulting from the conversion of forest into crop land whilst Duchicela et al. (2013) and Zombre (2003) observed a decrease in aggregate stability in cropland after decline in vegetation cover exposing soils to crusting or compaction. Accumulation of organic matter through litter decomposition, roots dynamics and soil biological activities (Bronick and Lal, 2005; Le Bissonnais et al., 2017) could also account for the higher meso and macro aggregates of the forest islands and savanna than croplands. Bronick and Lal. (2005) and Le Bissonnais et al. (2017) showed that roots act either by emeshment or by decompaction of the soil or by root exudations, which bind soil particles and increase cohesion. Organic carbon is a major binding agent of aggregates (Mentler et al., 2010)

The role of vegetation in forest land on macro-aggregates stability has also been attributed to diversity and species richness, which is associated with functional diversity (Pagliai et al., 2004; Six et al., 2004; Ouattara et al., 2008; Gould, 2016). Indeed, vegetation cover may moderate the impact of drying-wetting (Bronick and Lal, 2005) with the litter protecting the soil from the splash effect of the rains and the phenomena of suddent drying-wetting of the soil (Le Bissonnais et al., 2017). The roots increase the magnitude of the drying-wetting cycle, promoting the structural stability of the soil. This may be one further reason for the higher meso and macro-aggregates observed in the forest islands and savanna than crop lands (Table 3).

Our results showed significant correlation between soil properties and aggregates and this was confirmed by the very strong association between $f_{\text {meso }}$ and $f_{\text {macro }}(p<0.0001)$. It showed (Figure 2 and Table 2$)$, confirming that accumulation of organic carbon can improve aggregate stability and the soil's resilience to erosive forces. Positive relationships between iron oxides content and soil stability have also been reported under cotton cropping systems in the Sudan zone of Burkina Faso (Ouattara, 2007; Ouattara, 2008). Iron oxides are key components of clay minerals (Six et al., 2004) as they serve as flocculants, binding fine particles to organic molecules (Borggaard, 1983) with improved effects on aggregation. Römkens and Lindbo (1998) showed that aggregation in soils was enhanced from combination of organic material, iron-aluminium oxides and clay minerals. . .

\section{Conclusions}

Soil micro aggregate stability was not affected by land-use type but did systematically increase with greater annual precipitation in West Africa whereas the larger fractions were influenced directly by land use type, being systematically lower in agricultural soils than either natural savanna or in forest islands. Soil organic carbon content and iron oxides were key determinants of aggregates stability in the region. Contrary to our original hypothesis, these were, however, no differences in 
https://doi.org/10.5194/soil-2019-87

Preprint. Discussion started: 8 January 2020

(c) Author(s) 2020. CC BY 4.0 License.

aggregate stability between FI and SA. This suggests that other soil physical and chemical factors must underlie the West African forest island phenomenon.

6. Acknowledgments: The authors are grateful to the Royal Society-DFID for funding the study through the Soil of Forest Island in Africa (SOFIIA) ACBI project. We also thank the local village occupants for their collaboration and field assistance.

\section{References}

An, S., Mentler, A., Mayer, H. and Blum, W.: Soil aggregation, aggregate stability, organic carbon and nitrogen in different soil aggregate fractions under forest and shrub vegetation on the Loess Plateau, China, CATENA, 81(3), 226-233, doi:10.1016/j.catena.2010.04.002, 2010.

Bach, E. M. and Hofmockel, K. S.: A time for every season: soil aggregate turnover timulates decomposition and reduces carbon loss in grasslands managed for bioenergy, GCB Bioenergy, 8(3), 588-599, doi:10.1111/gcbb.12267, 2015.

Barthès, B. and Roose, E.: Aggregate stability as an indicator of soil susceptibility to runoff and erosion; validation at several levels, CATENA, 47(2), 133-149, doi:10.1016/s0341-8162(01)00180-1, 2002.

Bernoulli, D. "Specimen theoriae novae de Mensura Sortis." Commentarii Academiae Scientiarum Imperialis Petropolitanae 5: 175-92. 1738 .

Berendse, F., van Ruijven, J., Jongejans, E. and Keesstra, S.: Loss of plant species diversity reduces soil erosion resistance, Ecosystems, 18(5), 881-888, doi:10.1007/s10021-015-9869-6, 2015.

Bloin, M., Philippy, R. et Bartoli, F.: Dossier de valorisation d'un prototype de désagrégation des sols. Institut National de la Propriété Industrielle, Paris.: 16 p. 1990.

Bongiovanni, M. and Lobartini, J.: Particulate organic matter,carbohydrate, humic acid contents in soil macro and microaggregates as affected by cultivation, Geoderma, 136(3-4), 660-665, doi:10.1016/j.geoderma.2006.05.002, 2006.

Borggaard, O.: Iron oxides in relation to aggregation of soil particles, Acta Agriculturae Scandinavica, 33(3), 257-260, doi:10.1080/00015128309439889, 1983.

Bouajila, A. and Gallali, T.: Soil organic carbon fractions and aggregate stability in carbonated and no carbonated soils in Tunisia, Journal of Agronomy, 7(2), 127-137, doi:10.3923/ja.2008.127.137, 2008.

Bronick, C. and Lal, R.: Soil structure and management: a review, Geoderma, 124(1-2), 3-22, doi:10.1016/j.geoderma.2004.03.005, 2005.

Cerdà, A.: Aggregate stability against water forces under different climates on agriculture land and scrubland in southern Bolivia, Soil and Tillage Research, 57(3), 159-166, doi:10.1016/s0167-1987(00)00155-0, 2000.

Chartier, M., Rostagno, C. and Pazos, G.: Effects of soil degradation on infiltration rates in grazed semiarid rangelands of northeastern Patagonia, Argentina, Journal of Arid Environments, 75(7), 656-661, doi:10.1016/j.jaridenv.2011.02.007, 2011.

Duchicela, J., Sullivan, T., Bontti, E. and Bever, J.: Soil aggregate stability increase is strongly related to fungal community succession along an abandoned agricultural field chronosequence in the Bolivian Altiplano, Journal of Applied Ecology, n/a-n/a, doi:10.1111/1365-2664.12130, 2013.

Erktan, A., Cécillon, L., Graf, F., Roumet, C., Legout, C. and Rey, F.: Increase in soil aggregate stability along a Mediterranean successional gradient in severely eroded gully bed ecosystems: combined effects of soil, root traits and plant community characteristics, Plant and Soil, 398(1-2), 121-137, doi:10.1007/s11104-015-2647-6, 2015.

Ezebilo, E. E.: Threats to sustainable forestry development in Oyo State, Nigeria, masters/thesis, 1-42 pp., 2004. 
https://doi.org/10.5194/soil-2019-87

Preprint. Discussion started: 8 January 2020

(c) Author(s) 2020. CC BY 4.0 License.

Fairhead, J. and Leach, M.: Reframing deforestation. Global analyses and local realities: studies in West Africa. London and New York: Routledge, 1998.

Fairhead, J. and Leach, M.: False forest history, complicit social analysis: Rethinking some West African environmental narratives, World Development, 23(6), 1023-1035, doi:10.1016/0305-750x(95)00026-9, 1995.

Gould, I. J., Quinton, J. N., Weigelt, A., De Deyn, G. B. and Bardgett, R. D.: Plant diversity and root traits benefit physical properties key to soil function in grasslands, edited by E. Seabloom, Ecology Letters, 19(9), 1140-1149, doi:10.1111/ele.12652, 2016.

Hanke, D. and Dick, D.: Aggregate Stability in soil with humic and histic horizons in a toposequence under Araucaria Forest, Revista Brasileira de Ciência do Solo, 41(0), doi:10.1590/18069657rbcs20160369, 2017.

Hanke, D., Melo, V., Dieckow, J., Dick, D. and Bognola, I.: Influência da Matéria Orgânica no Diâmetro Médio de Minerais da Fração Argila de Solos Desenvolvidos de Basalto no Sul do Brasil, Revista Brasileira de Ciência do Solo, 39(6), 1611 1622, doi:10.1590/01000683rbcs20140655, 2015.

Jones, E. W.: The Forest outliers in the Guinea zone of northern Nigeria, The Journal of Ecology, 51(2), 415, doi:10.2307/2257694, 1963.

Kokou, K. and Sokpon, N.: Les forêts sacrées du Couloir Du Dahomey, Bois Et Forêts Des Tropiques, $288(2), 2006$.

Le Bissonnais, Y., Prieto, I., Roumet, C., Nespoulous, J., Metayer, J., Huon, S., Villatoro, M. and Stokes, A.: Soil aggregate stability in Mediterranean and tropical agro-ecosystems: effect of plant roots and soil characteristics, Plant and Soil, 424(1-2), 303-17, doi:10.1007/s11104-017-3423-6, 2017.

Legout, C., Leguedois, S. and Le Bissonnais, Y.: Aggregate breakdown dynamics under rainfall compared with aggregate stability measurements, European Journal of Soil Science, 56(2), 225-238, doi:10.1111/j.1365-2389.2004.00663.x, 2005. Mataix-Solera, J., Cerdà, A., Arcenegui, V., Jordán, A. and Zavala, L.: Fire effects on soil aggregation: A review, EarthScience Reviews, 109(1-2), 44-60, doi:10.1016/j.earscirev.2011.08.002, 2011.

Mathieu, C., Pieltain, F.: Analyse Physique Des Sols: Methodes Choisies. Lavoisier. Paris,1998.

Mehrotra, S.: On the Implementation of a Primal-Dual Interior Point Method, SIAM Journal on Optimization, 2(4), 575-601, doi:10.1137/0802028, 1992.

Mikutta, R., Zang, U., Chorover, J., Haumaier, L. and Kalbitz, K.: Stabilization of extracellular polymeric substances (Bacillus subtilis) by adsorption to and coprecipitation with Al forms, Geochimica et Cosmochimica Acta, 75(11), 3135-3154, doi:10.1016/j.gca.2011.03.006, 2011.

Ouattara, K., Ouattara, B., Assa, A. and Sédogo, P.: Long-term effect of ploughing, and organic matter input on soil moisture characteristics of a Ferric Lixisol in Burkina Faso, Soil and Tillage Research, 88(1-2), 217-224, doi:10.1016/j.still.2005.06.003, 2006.

Ouattara, korodjouma: Improved soil and water conservatory managements for cotton-maize rotation system in the western cotton Area of Burkina Faso, PhD-thesis. Swedish University of Agricultural Sciences Umeå., 2007.

Ouattara, K., Ouattara, B., Nyberg, G., Sédogo, M. and Malmer, A.: Effects of ploughing frequency and compost on soil aggregate stability in a cotton-maize (Gossypium hirsutum-Zea mays) rotation in Burkina Faso, Soil Use and Management, 24(1), 19-28, doi:10.1111/j.1475-2743.2007.00129.x, 2008.

Pagliai, M., Vignozzi, N. and Pellegrini, S.: Soil structure and the effect of management practices, Soil and Tillage Research, 79(2), 131-143, doi:10.1016/j.still.2004.07.002, 2004.

Rhoton, F.E., Lindbo, D.L. and Römkens, M.: Iron oxides-erodibility interactions for soils of the Memphis Catena, Soil Science Society of America Journal, 62(6), NP, doi:10.2136/sssaj1998.03615995006200060038x, 1998.

Six, J., Elliott, E. and Paustian, K.: Soil macroaggregate turnover and microaggregate formation: a mechanism for C sequestration under no-tillage agriculture, Soil Biology and Biochemistry, 32(14), 2099-2103, doi: 10.1016/s00380717(00)00179-6, 2000. 
https://doi.org/10.5194/soil-2019-87

Preprint. Discussion started: 8 January 2020

(c) Author(s) 2020. CC BY 4.0 License.

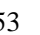

Six, J., Bossuyt, H., Degryze, S. and Denef, K.: A history of research on the link between (micro)aggregates, soil biota, and soil organic matter dynamics, Soil and Tillage Research, 79(1), 7-31, doi:10.1016/j.still.2004.03.008, 2004.

Sobey, D. G.: Anogeissus groves on abandoned village sites in theMole National Park, Ghana. Biotropica 10:87-99, 1978.

Tisdall, J. M. and Oades, J. M.: Organic matter and water-stable aggregates in soils, Journal of Soil Science, 33(2), 141-163, doi:10.1111/j.1365-2389.1982.tb01755.x, 1982.

Wang, Z., Hou, Y., Fang, H., Yu, D., Zhang, M., Xu, C., Chen, M. and Sun, L.: Effects of plant species diversity on soil conservation and stability in the secondary succession phases of a semihumid evergreen broadleaf forest in China, Journal of Soil and Water Conservation, 67(4), 311-320, doi:10.2489/jswc.67.4.311, 2012.

Zombre, N. P.: Les sols tres degrades 'Zipella' du Centre Nord Du Burkina Faso : Dynamique, caracteristiques morpho-biopedologiques et impacts des techniques de restauration sur leur Productivite., Thèse De Doctorat D’état En sciences naturelles, 374 pp., Université de Ouagadougou., 2003.

(1)

7

(1)

0

1

2

4

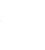

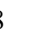
(2)

3

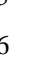

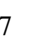

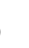
50 51 
https://doi.org/10.5194/soil-2019-87

Preprint. Discussion started: 8 January 2020

(c) Author(s) 2020. CC BY 4.0 License.

354 Table 1: Details of study sites including land use type (cropland $=0$, forest island $=1$, natural savanna $=2$ ), geographical

355 coordinates, mean daily temperature of the coldest month $\left(T_{\min }\right)$, mean daily temperature of the hottest month $\left(T_{\max }\right)$, mean

356 annual precipitation $\left(P_{\mathrm{A}}\right)$ and WRB soil classification.

\begin{tabular}{|c|c|c|c|c|c|c|c|}
\hline Sites & $\begin{array}{c}\text { Land } \\
\text { use }\end{array}$ & Lat & Long & $\begin{array}{l}T_{\min } \\
\left({ }^{\circ} \mathbf{C}\right)\end{array}$ & $T_{\max }\left({ }^{\circ} \mathbf{C}\right)$ & $\boldsymbol{P}_{\mathbf{A}}(\mathbf{m})$ & Soil types \\
\hline $\begin{array}{l}\text { Koupela } \\
\text { (KPL) } \\
\text { (Burkina }\end{array}$ & 0 & 11.95157 & -2.40529 & 16.2 & 38.8 & 0.81 & Lixisol (Arenic, Rhodic) \\
\hline \multirow[t]{2}{*}{ Faso) } & 1 & 11.95051 & -2.40536 & 16.2 & 38.8 & 0.81 & Lixisol (Arenic, Rhodic) \\
\hline & 2 & 12.09921 & -2.25859 & 15.8 & 38.9 & 080 & Eutric Plinthosol (Lixic, Loamic) \\
\hline $\begin{array}{l}\text { Toece (TOE) } \\
\text { (Burkina }\end{array}$ & 0 & 11.82644 & -1.22018 & 17.3 & 38.2 & 0.83 & Lixisol (Arenic, Rhodic) \\
\hline \multirow[t]{2}{*}{ Faso) } & 1 & 11.82578 & -1.22142 & 17.3 & 38.2 & 0.83 & Lixisol (Arenic, Rhodic) \\
\hline & 2 & 11.74883 & -1.21682 & 17.3 & 38.2 & 0.83 & Stagnic Pisoplithic Plinthosol (Lixic, Loamic) \\
\hline $\begin{array}{l}\text { Hounde } \\
\text { (HOU) } \\
\text { (Burkina }\end{array}$ & 0 & 11.52748 & -3.54269 & 17.0 & 38.0 & 0.91 & \\
\hline \multirow[t]{2}{*}{ Faso) } & 1 & 11.52774 & -3.54222 & 17.0 & 38.0 & 0.91 & Ferric Lixisol \\
\hline & 2 & 11.32041 & -3.26029 & 17.7 & 37.8 & 0.95 & Stagnic Lixisols (Loamic, Hypereutric) \\
\hline \multirow{3}{*}{$\begin{array}{l}\text { Kadomba } \\
\text { (KAD) } \\
\text { (Burkina } \\
\text { Faso) }\end{array}$} & 0 & 11.49749 & -3.99781 & 16.4 & 37.7 & 0.95 & Stagnic Lixisols (Loamic, Hypereutric) \\
\hline & 1 & 11.4987 & -3.9979 & 16.4 & 37.7 & 0.95 & Stagnic Lixisols (Loamic, Hypereutric) \\
\hline & 2 & 11.74883 & -4.21682 & 15.1 & 38.0 & 0.91 & Stagnic Lixisols (Loamic Hypereutric) \\
\hline $\begin{array}{l}\text { Navrongo } \\
\text { (NAG) }\end{array}$ & 0 & 10.86427 & -1.08127 & 18.9 & 38.4 & 0.91 & Stagnic Pisoplinthic Plinthosol (Lixic, Clayic) \\
\hline \multirow[t]{2}{*}{ (Ghana) } & 1 & 10.86466 & -1.08091 & 18.9 & 38.4 & 0.91 & Stagnic Pisoplinthic Plinthosol (Lixic, Clayic, Humic) \\
\hline & 2 & 10.78512 & -1.21984 & 19.0 & 38.2 & 0.98 & Stagnic Petric Plinthosol (Eutric,Arenic) \\
\hline $\begin{array}{l}\text { Changnaayili } \\
(\mathrm{CHN})\end{array}$ & 0 & 9.37016 & -0.70318 & 20.1 & 37.4 & 1.10 & Pisoplinthic Plinthosol (Loamic, Ochric) \\
\hline \multirow[t]{2}{*}{ (Ghana) } & 1 & 9.37222 & -0.70375 & 20.1 & 37.4 & 1.10 & Pisoplinthic Plinthosol (Abruptic, Loamic) \\
\hline & 2 & 9.39866 & -0.59398 & 19.9 & 37.3 & 1.12 & Stagnic Petric Plinthosol (Eutric,Arenic) \\
\hline $\begin{array}{l}\text { Nkoranza } \\
\text { (NKZ) }\end{array}$ & 0 & 7.5354 & -1.70812 & 19.5 & 33.6 & 1.27 & Abruptic Chromic Lixisol (Loamic, Cutanic, Profondic) \\
\hline \multirow[t]{2}{*}{ (Ghana) } & 1 & 7.56341 & -1.71302 & 19.5 & 33.6 & 1.27 & Abruptic Chromic Lixisol (Loamic, Cutanic, Profondic) \\
\hline & 2 & 7.65579 & -1.64400 & 20.1 & 34.6 & 1.24 & Abruptic Chromic Lixisol (Loamic, Cutanic, Profondic) \\
\hline $\begin{array}{l}\text { Wasim } \\
\text { Okuta } \\
\text { (WSM) }\end{array}$ & 0 & 7.53256 & 2.76823 & 20.8 & 35.4 & 1.12 & Eutric petroplinthic Cambisol \\
\hline \multirow[t]{2}{*}{ (Nigeria) } & 1 & 7.52827 & 2.76886 & 20.8 & 35.4 & 1.12 & Eutric Arenosol (Humic) \\
\hline & 2 & 7.52708 & 2.76785 & 20.8 & 35.4 & 1.12 & Rhodiv Luvisol (Arenic) \\
\hline Ilua (ILU) & 0 & 8.0045 & 3.40821 & 19.2 & 34.8 & 1.16 & Plinthosol (Arenic, Eutric) \\
\hline \multirow[t]{2}{*}{ (Nigeria) } & 1 & 8.00307 & -3.40896 & 20.0 & 35.0 & 1.07 & Rhodic Luvisol (Clayic) \\
\hline & 2 & 7.9994 & 3.44503 & 20.0 & 35.0 & 1.15 & Ferric Lixisol \\
\hline $\begin{array}{l}\text { Onikpataku } \\
\text { (ONP) }\end{array}$ & 0 & 7.39044 & 3.02113 & 21.4 & 35.0 & 1.13 & Lixisol (Arenic, Rhodic) \\
\hline \multirow[t]{2}{*}{ (Nigeria) } & 1 & 7.38982 & 3.02017 & 21.4 & 35.0 & 1.13 & Plinthosl (Lixic) \\
\hline & 2 & 7.39691 & 3.02048 & 21.4 & 35.0 & 1.13 & Plinthosol (Clayic, Eutric) \\
\hline $\begin{array}{l}\text { Elewere } \\
\text { (ELE) }\end{array}$ & 0 & 8.03883 & 3.44167 & 19.2 & 34.8 & 1.16 & Plinthosol (Arenic) \\
\hline \multirow[t]{2}{*}{ (Nigeria) } & 1 & 8.041 & 3.44171 & 19.2 & 34.8 & 1.16 & Rhodic Luvisol (Clayic) \\
\hline & 2 & 8.0425 & 3.44224 & 19.2 & 34.8 & 1.16 & Eutric Cambisol (Arenic) \\
\hline
\end{tabular}


https://doi.org/10.5194/soil-2019-87

Preprint. Discussion started: 8 January 2020

(c) Author(s) 2020. CC BY 4.0 License.

Table 2: Estimates for linear mixed effects models relating variation in $\log \times$ arcsine transformed aggregate fractions to precipitation and land-use type. For this analysis Mean Annual Precipitation $P_{\mathrm{A}}$ estimates for each site have been centred on the dataset mean value of $1.01 \mathrm{~m} \mathrm{a}^{-1}$

\begin{tabular}{|c|c|c|c|c|c|c|c|c|c|}
\hline \multirow[b]{2}{*}{ Fixed effect } & \multicolumn{3}{|c|}{$\begin{array}{c}\text { Microaggregates } \\
R_{\mathrm{m}}^{2}=\mathbf{0 . 1 7}, R_{\mathrm{c}}^{2}=\mathbf{0 . 5 9}\end{array}$} & \multicolumn{3}{|c|}{$\begin{array}{c}\text { Mesoaggregates } \\
R_{\mathrm{m}}^{2}=\mathbf{0 . 1 4}, R_{\mathrm{c}}^{2}=\mathbf{0 . 8 2}\end{array}$} & \multicolumn{3}{|c|}{$\begin{array}{l}\text { Macroaggregates } \\
R_{\mathrm{m}}^{2}=\mathbf{0 . 1 4}, R_{\mathrm{c}}^{2}=\mathbf{0 . 8 2}\end{array}$} \\
\hline & Coef. & S.E & $\mathrm{t}$ & Coef. & S.E & $\mathrm{t}$ & Coef. & S.E & $\mathrm{t}$ \\
\hline Intercept (Agricultural field) & -0.030 & 0.0036 & -0.82 & -0.805 & 0.101 & -7.94 & -0.990 & 0.127 & -7.82 \\
\hline$P_{\mathrm{A}}(\mathbf{m})$ & 0.976 & 0.272 & 3.58 & 0.180 & 0.418 & 0.43 & 0.467 & 0.522 & 0.89 \\
\hline Forest island & 0.007 & 0.093 & 0.07 & 0.354 & 0.141 & 2.50 & 0.383 & 0.177 & 2.17 \\
\hline Savanna & -0.003 & 0.095 & -0.04 & 0.227 & 0.142 & 1.60 & 0.401 & 0.177 & 2.27 \\
\hline Sampling depth & -0.086 & 0.029 & -2.97 & -0.141 & 0.024 & -5.90 & -0.106 & 0.029 & -3.62 \\
\hline Random Component & \multicolumn{3}{|c|}{ Parameter } & \multicolumn{3}{|c|}{ Parameter } & \multicolumn{3}{|c|}{ Parameter } \\
\hline Within plot variance & \multicolumn{3}{|c|}{0.0097} & \multicolumn{3}{|c|}{0.0190} & \multicolumn{3}{|c|}{0.0177} \\
\hline Between plot variance & \multirow{2}{*}{\multicolumn{3}{|c|}{0.0387}} & \multicolumn{3}{|c|}{0.1086} & \multirow{2}{*}{\multicolumn{3}{|c|}{0.1735}} \\
\hline Residual variance & & & & \multicolumn{3}{|c|}{0.0337} & \multicolumn{2}{|r|}{0.0528} & \\
\hline
\end{tabular}

364

365

\begin{tabular}{|c|c|c|c|}
\hline $\begin{array}{l}\text { Aggregates }(\%) \\
\text { Land use }\end{array}$ & Macro aggregates & Meso aggregates & Micro aggregates \\
\hline Cropland & $15.9 \pm 2.4^{b}$ & $17.8 \pm 2.1^{\mathrm{b}}$ & $73.6 \pm 1.9^{\mathrm{a}}$ \\
\hline Forest island & $32.3 \pm 2.2 \mathrm{a}$ & $35.8 \pm 1.9^{\mathrm{a}}$ & $73.5 \pm 1.8^{\mathrm{a}}$ \\
\hline *Savanna & $32.0 \pm 2.1^{\mathrm{a}}$ & $31.0 \pm 1.8^{\mathrm{a}}$ & $74.3 \pm 1.9^{\mathrm{a}}$ \\
\hline Probability value & $0.00 * * *$ & $0.000 * * *$ & $0.9 \mathrm{~ns}$ \\
\hline
\end{tabular}


https://doi.org/10.5194/soil-2019-87

Preprint. Discussion started: 8 January 2020

(c) Author(s) 2020. CC BY 4.0 License.

406

407

408

409

410

411

412

413

414

415

416

417

418

419

420

Table 4. Strength of association between the studied covariates as estimated by Kendall's $\tau$ (soil data for the 0 to $5 \mathrm{~cm}$ depth only). Symbols used: $f_{\text {micro }}=$ micoaggregate fraction, $f_{\text {meso }}=$ mesoaggregate fraction, $f_{\text {macro }}=$ macroaggregate fraction, $\left[\mathrm{Fe}_{\mathrm{o}}\right]=$ oxalate extractable iron concentration, $\left[\mathrm{Al}_{\mathrm{o}}\right]$ oxalate extractable aluminium concentration, $\left[\mathrm{Fe}_{\mathrm{d}}\right]=$ dithionite extractable iron concentration, $[\mathrm{Ald}]=$ dithionite extractable aluminium concentration, $\left[\mathrm{Fe}_{\mathrm{c}}\right]=$ pyrophosphate extractable iron concentration, $\left[\mathrm{Al}_{\mathrm{c}}\right]$ pyrophosphate extractable aluminium concentration, $[\mathrm{C}]=$ soil carbon concentration, $P_{\mathrm{A}}=$ mean annual precipitation. Relationships significant at $\mathrm{p}<0.01$ are shown in bold (with grey background) with those for which $0.01 \leq p \lesssim 0.05$ are shown in italics.

$\begin{array}{cccccccccccc}f_{\text {meso }} & 0.21 & & & & & & & & & \\ f_{\text {macro }} & 0.17 & \mathbf{0 . 7 0} & & & & & & & \\ {\left[\mathrm{Fe}_{\mathrm{o}}\right]} & -0.13 & 0.11 & 0.18 & & & & & & \\ {\left[\mathrm{Al}_{\mathrm{o}}\right]} & -0.11 & -0.24 & -0.16 & 0.23 & & & & & \\ {\left[\mathrm{Fe}_{\mathrm{d}}\right]} & -0.16 & 0.24 & 0.25 & 0.32 & -0.30 & & & & \\ {\left[\mathrm{Al}_{\mathrm{d}}\right]} & -0.16 & \mathbf{- 0 . 2 8} & -0.19 & 0.00 & \mathbf{0 . 7 0} & -0.33 & & & \\ {\left[\mathrm{Fe}_{\mathrm{c}}\right]} & -0.17 & 0.21 & 0.19 & -0.03 & \mathbf{- 0 . 5 2} & 0.64 & -0.40 & & \\ {\left[\mathrm{Al}_{\mathrm{c}}\right]} & -0.26 & -0.17 & -0.15 & -0.28 & 0.19 & -0.22 & 0.49 & 0.00 & & \\ {[\mathrm{C}]} & 0.00 & 0.26 & \mathbf{0 . 4 2} & 0.19 & 0.01 & 0.18 & -0.02 & 0.07 & -0.05 & \\ P_{\mathrm{A}} & \mathbf{0 . 5 0} & 0.18 & 0.06 & -0.13 & -0.19 & -0.18 & -0.23 & -0.13 & -0.22 & 0.03 \\ & f_{\text {micro }} & f_{\text {meso }} & f_{\text {macro }} & {\left[\mathrm{Fe}_{\mathrm{o}}\right]} & {\left[\mathrm{Al}_{\mathrm{o}}\right]} & {\left[\mathrm{Fe}_{\mathrm{d}}\right]} & {\left[\mathrm{Al}_{\mathrm{d}}\right]} & {\left[\mathrm{Fe}_{\mathrm{c}}\right]} & {\left[\mathrm{Al}_{\mathrm{c}}\right]} & {[\mathrm{C}]}\end{array}$


https://doi.org/10.5194/soil-2019-87

Preprint. Discussion started: 8 January 2020

(c) Author(s) 2020. CC BY 4.0 License.

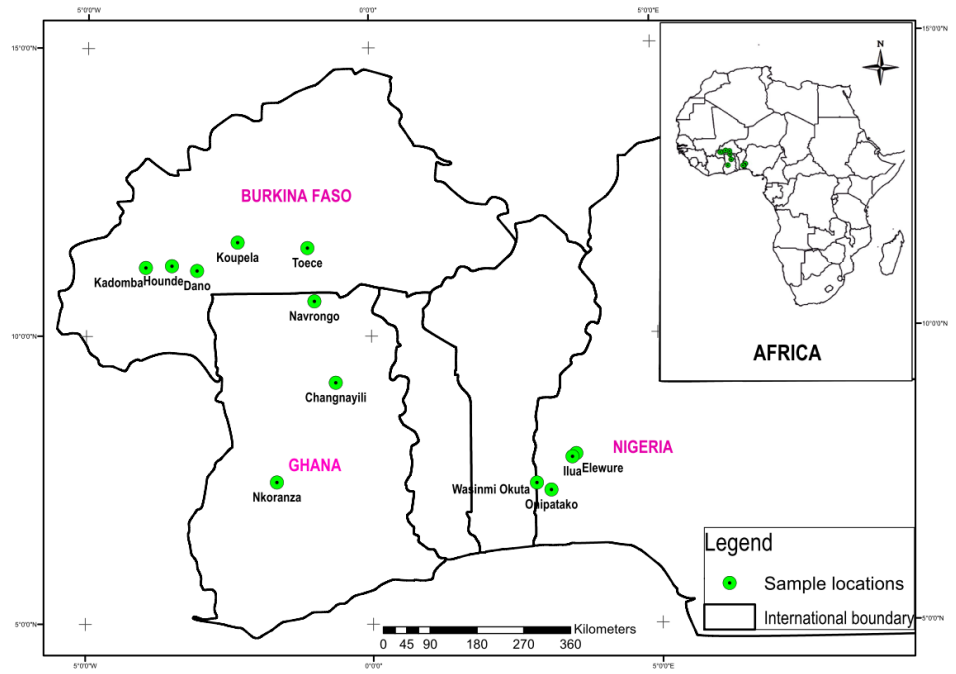

Figure 1: Location of study areas. 
https://doi.org/10.5194/soil-2019-87

Preprint. Discussion started: 8 January 2020

(C) Author(s) 2020. CC BY 4.0 License.

Son EGG

450
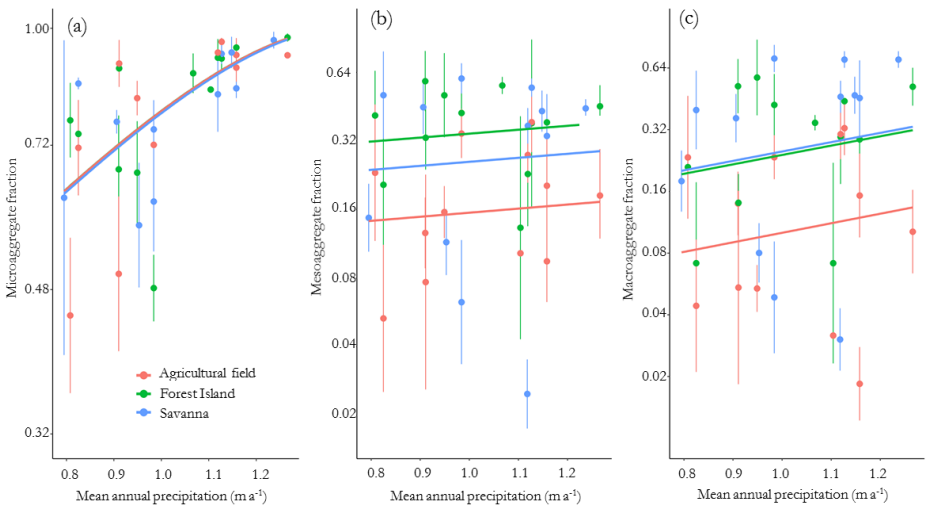

451

452

453

454

455

456

457

458

459

460

Figure 2. Effect of land-use and mean annual precipitation on 0 to $5 \mathrm{~cm}$ depth aggregate fractions. (a) microaggregates; (b) mesoaggregates; (c) macroaggregates. Symbol and line colours as are indicated in panel (a), with the fitted lines representing the fixed component of the model fits as summarised in Table 2.

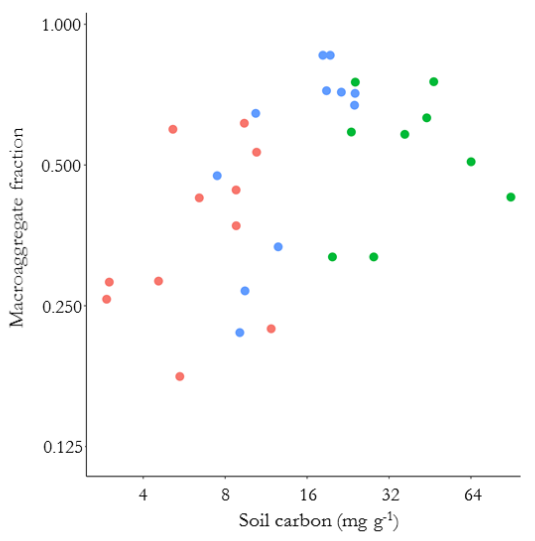

461

Figure 3. Relationship between soil carbon content and macro-aggregate fractions ( 0 to $5 \mathrm{~cm}$ depth). Symbols as in Figure 2 . 